\title{
TRENDS IN THE PUBLIC SECTOR
}

\section{WHY POLITICIANS PREFER QUASI-AUTONOMOUS ORGANIZATIONS}

\author{
Sandra van Thiel
}

\begin{abstract}
Since the 1980s the number of quasi-autonomous non-governmental organizations has increased in most western countries. This article offers a theoretical explanation for politicians' apparent preference for quangos. The model is based on rational choice sociology, neo-institutional economics and public choice. Hypotheses are formulated on the conditions that are expected to influence politicians' choice. The statistical analysis, using a database of 124 decisions to establish 392 quangos in The Netherlands between 1950 and 1993 , shows that quango proliferation is more a trend than a well-informed choice. This raises new questions for research.
\end{abstract}

KEY WORDS $\bullet$ administrative reform $\bullet$ quangos $\bullet$ rational choice theory

\section{Introduction}

In many western states from the 1980s on administrative reforms have transformed the way in which governments are organized and operate. Privatization, competitive tendering and giving agencies freedom to manage are all examples of such reforms (see, among others, Osborne and Gaebler, 1992; Hood, 1994; Kettl, 1997; Pollitt and Bouckaert, 2000). This article will focus on the proliferation of so-called quangos; quasi-autonomous nongovernmental organizations (Barker, 1982). In short, quangos carry out public tasks but operate at arm's length of the government. Their number increased strongly during the 1980s and 1990s.

After discussing the quango concept in more depth, I will go into the motives of politicians for using quangos to carry out public tasks. This article will present and test an explanation that is based on rational choice sociology, neo-institutional economics and public choice. A model is developed to predict under which conditions politicians will choose quangos for policy implementation rather than government bureaucracy. Hypotheses 
are formulated and tested statistically. ${ }^{1}$ The results will show that quango proliferation is more a trend than a deliberate choice. This raises new questions for research.

\section{Definition of a Quango}

Quangos are organizations which, as their main task, are charged with the implementation of one or more public policies and which are funded publicly but operate at arm's length of the central government, without an immediate hierarchical relationship existing with a minister or a parent department. A more precise definition is hard to find. As a consequence, different researchers and practitioners list different types of organizations as quangos. For example, in the United Kingdom the estimated number of quangos ranges between more than 6000 (Hall and Weir, 1996) and just over 300 (Hogwood, 1995).

To find a useful solution to this definition problem, it is necessary to acknowledge that there is not just one type of quango. Instead, there are several types of organizations that could be classified as quangos. Following this idea, Table 1 presents a subsectional map of quasi-autonomous organizations (taken from Greve et al., 1999).

Table 1 shows four types of organizations: (1) contract agencies (see the British Next Steps agencies), (2) public bodies (e.g. non-departmental public bodies, para- or extra-governmental organizations and the Dutch ZBOs [short for zelfstandige bestuursorganen]), (3) voluntary or charity organizations and (4) state-owned enterprises (SOEs). Examples are given for each type of quango, from three countries: the United Kingdom, Denmark and The Netherlands. All empirical references in this article will be to quangos of the 'public body' type, for reasons explained later.

The typology of quasi-autonomous organizations is based on the assumption that the conditions under which an organization operates determine what type it is. Table 1 lists three conditions: (1) financial arrangements, (2) the extent to which ministerial accountability applies and (3) the control mechanisms for ministers. The type of task is not included as a distinctive condition, because different types of quangos can be charged with similar tasks. Going through the table from right to left, one will notice the turning point in the middle, where opportunities for politicians to exert influence (control mechanisms, ministerial accountability and finances) decrease and the autonomy of quangos increases. Autonomy is defined as the ownership of the rights of production, i.e. who decides about or provides the organiza-

1. This article presents the summarized version of a larger argument. See Van Thiel (2001) for more elaboration and for a study of quango performance. 
Table 1. Subsectional map of quangos (taken from Greve et al., 1999)

\begin{tabular}{|c|c|c|c|c|}
\hline & $\begin{array}{l}\text { Privatization/ semi } \\
\text { privatization }\end{array}$ & Voluntary/charity & Public body & Contract agency \\
\hline Definition & $\begin{array}{l}\text { Former state-owned } \\
\text { company now wholly or } \\
\text { partly privatized }\end{array}$ & $\begin{array}{l}\text { Bottom-up body } \\
\text { performing public } \\
\text { function }\end{array}$ & $\begin{array}{l}\text { At arm's length but } \\
\text { publicly funded }\end{array}$ & $\begin{array}{l}\text { Quasi-autonomous part of } \\
\text { department }\end{array}$ \\
\hline Finances & $\begin{array}{l}\text { Capital market, stock } \\
\text { exchange }\end{array}$ & Donations, subsidy & State budget or levying & State budget \\
\hline Ministerial responsibility & No & No & Partial & Yes \\
\hline Control mechanism & Market regulation & Co-op, contract & Statutes & Framework document \\
\hline Public task & Yes & Yes & Yes & Yes \\
\hline Public domain & No & Yes & Yes & Yes \\
\hline UK & British Rail & Shelter & Regulators, TECs & Prison Service \\
\hline The Netherlands & Postal Services & Salvation Army & $\begin{array}{l}\text { Police authorities, } \\
\text { Legal aid }\end{array}$ & Meteorological Office \\
\hline Denmark & Copenhagen Airport & Danish Sport Association & National bank & Patent Office \\
\hline
\end{tabular}


tion with goals, tasks, budget, input variables such as labor and capital, output and/or outcome, prices of supplied goods or services and the production process.

Quangos are quasi-autonomous, which means that they are given some of the production rights but not all. Part of the production rights remains the prerogative of the minister of the parent department. There is no uniform arrangement in this matter, as every single quango, irrespective of its type, owns a different set of production rights. In general, most quangos receive relative managerial freedom: managing the production process (input, output and procedures) is their own responsibility. The minister is no longer accountable for managerial affairs. The minister does remain accountable for policy matters, the choice of a quango and supervision of quangos. A limited ministerial responsibility is accompanied by fewer control mechanisms for ministers (Stone, 1995). Due to the mixed ownership of production rights, quangos are not public organizations in the traditional sense, as, for example, departmental units, although they do belong to the public domain.

It would be a mistake to assume that quangos are entirely new organizations. In most western countries, they have a longstanding tradition. For example, the Dutch ZBOs are a type of public body that has been in use for decades or even centuries (Leeuw and Van Thiel, 1999). The same goes for non-departmental bodies in the United Kingdom, Crown entities in New Zealand, VOIs in Flanders, and state-owned enterprises in Sweden, Finland and Denmark (Hood and Schuppert, 1988; Modeen and Rosas, 1988; Flinders and Smith, 1999; Greve, 1999; Wistrich, 1999). However, the number of quangos has increased rapidly from the 1980s on. See, for example, Figure 1 which displays the increase in the number of ZBOs in The Netherlands. Based on inventories made in 1993 (Algemene Rekenkamer, 1995) and 2000 (Van Thiel and Van Buuren, 2001), Figure 1 shows in which years ZBOs were established. A strong increase in the 1980s and 1990s is clearly visible.

A comparison over time shows that ZBOs are seldom abolished (3 percent in 1980s and 6 percent in 1990s) but they are often merged and re-organized (about one out of five cases) or subject to re-definitions (Van Thiel and Van Buuren, 2001). Ergo, the position of an organization on the quango continuum need not be constant over time. Quango drift can occur; for example, an agency can become a public body or a privatized organization can be renationalized.

\section{Politicians' Motives for Choosing Quangos: Practitioner Theory}

Politicians mention different motives for their choice of quangos, that is if they mention any. There seems to be a general lack of justification by 


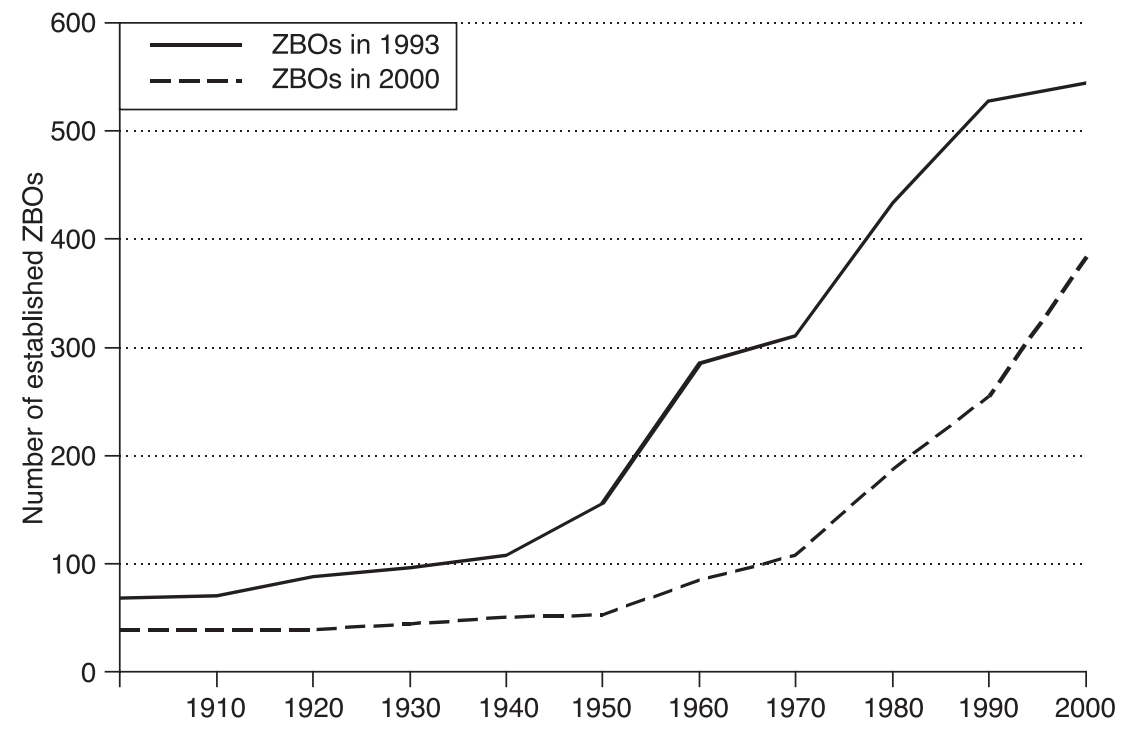

Figure 1. Rate of Establishment of ZBOs in The Netherlands, 1900-2000

(Source: Van Thiel, 2001)

politicians for the use of quangos (except in New Zealand; see Boston, 1995). When they do mention a motive, politicians usually expect an increase in the efficiency and effectiveness of policy implementation, they hope to bring the government closer to the citizens by putting policy implementation at arm's length or by leaving matters to social groups (self-regulation) or they want to leave policy implementation to independent experts. The sum of these expectations will be referred to in this article as being the 'practitioner theory' of quangos. Other motives are ascribed to politicians as well, such as the use of quangos to circumvent other levels of government (e.g. municipalities) or patronage i.e. rewarding political friends by appointing them as quango board members.

\section{Theoretical Model: Premises}

Rather than using practitioner theory, this article proposes another explanation of politicians' choice for quangos. It builds on rational choice sociology (Lindenberg, 1983, based on work by Adam Smith; Coleman, 1990) combined with elements from neo-institutional economic approaches (Williamson, 1989; Pratt and Zeckhauser, 1991) and public choice (Mueller, 1989, 1997; Dunleavy, 1991, 1994, based on work originated by Downs, 1965 and Niskanen, 1975). This combination is possible because all theories 
mentioned are based on a rational actor model of man. To ascertain the causes of quango proliferation, it is necessary to determine under which conditions politicians choose quangos as executive agent, rather than government bureaucracy.

Two premises are fundamental to the proposed explanation of quango proliferation. The first premise is that macro phenomena can be explained by using certain assumptions about the behavior of individuals and the conditions or constraints under which they act (methodological individualism). In the problem situation at hand, two actors will be distinguished, both of whom should be considered as key actors: (1) the legislature and (2) the executive agent. The behavior of these corporate actors is the aggregated behavior of individuals. On the basis of certain assumptions about the behavior of individuals, the macro behavior of the two corporate actors will be predicted or explained (Coleman, 1990: 541). ${ }^{2}$ Of course, this is a strong simplification, which does not do justice to the empirical complexity of the problem. Moreover, in reality, other actors, such as interest groups and civil servants, will play an important role in the process of quango proliferation as well. I will return to this point later on.

The second premise is that the behavior of individuals is rational, that is they pursue goals. By achieving goals in the most efficient way, actors can maximize their expected utility. According to the social production function approach - based on work originated by Adam Smith - the two universal goals for all individuals are physical well-being and social approval (see, for example, Lindenberg and Frey, 1993). These universal goals are reached by way of intermediary, or instrumental, goals. The achievement of goals is restricted by the amount and type of resources an actor has at his disposal and the constraints he faces. By determining their intermediary goals and constraints, the behavior of (corporate) actors can be modeled and testable hypotheses formulated. Such a constraint-driven approach offers a simplified way of modeling individuals' behavior. By introducing the concept of uncertainty, some of these simplifications will be relaxed during the development of the theoretical model later.

It is important to keep in mind that the model presented here is but a first step in the explanation of quango proliferation. The last section of this article provides a number of recommendations for further elaboration of the model and future research.

2. This approach is supported by Scharpf, who - concerning the application of methodological individualism to political processes - said that '[i]n the politicial process . . . the most relevant actors are typically acting in the interest, and from the perspective, of larger units, rather than for themselves. This allows us to simplify analysis by treating a limited number of large units as composite (i.e., aggregate, collective, or corporate) actors with relatively cohesive action orientations ...'(1997: 12). 


\section{The Choice of Legislature for an Executive Agent}

The corporate actor 'legislature' comprises all elected politicians. As agents acting on behalf of the citizens, politicians will aim their behavior at fulfilling the goals of voters, who are their principals. However, politicians have their own goals as well. Following public choice theory, a politician's physical well-being and social approval is dependent on his being re-elected (see, e.g., Downs, 1965; Mueller, 1989; Dunleavy, 1991). If he is not re-elected, a politician cannot continue his job and obtain the benefits that enable him to maximize physical well-being and social approval. Being a politician allows one (1) to acquire the wealth and/or power associated with being a politician; (2) to propagate and implement ideologies, beliefs or opinions; and (3) to attain (more) electoral support.

To gain and keep the support of voters necessary for re-election, politicians will adopt policies favorable to the electorate. For the implementation of those policies, they have to choose an executive agent. Here, politicians are given the choice between only two types of agents: government bureaucracy or a quango. Their choice will be determined by the extent to which it can contribute to the maximization of the number of supportive votes.

\section{Advantages and Disadvantages of Choosing Quangos}

Choosing a quango as an executive agent implies the transfer of (some of) the production rights, which means a reduction in the responsibility of politicians for policy implementation. Limited responsibility reduces political risks, such as loss of electoral support, because politicians can no longer be held accountable for bad policy implementation (see Cohn, 1997). ${ }^{3}$ However, it becomes difficult for politicians to benefit from successful policy implementation, it no longer being ascribed to them directly. Politicians can, however, claim to have made the right choice.

Limited responsibility does not imply any responsibility at all. Some responsibility remains, for example, for the choice for a quango, the budgets given to quangos and the supervision or regulation of quangos.

Besides limiting responsibility, the transfer of production rights is advantageous to politicians in another way. The fact that a bureaucracy does not

3. Often politicians remain responsible 'by reputation'. Even though policy implementation has been hived off and is formally no longer the responsibility of politicians, a failing quango is still considered a public affair, both by voters and the media. This has already led to some 'scandals', where politicians were held accountable or even forced to resign because of the poor performance of a quango (e.g. the prison service [a Next Steps agency] in the UK and the regulator of social security [Ctsv, a ZBO] in The Netherlands). 
own any production rights is inherent to it being designed to be impartial or neutral. Quangos, however, can be used by politicians to enhance the commitment of (new) supportive (groups of) voters. For example, interest groups can be charged with policy implementation and, thus, become a quango ('hiving in') or they can be appointed members of a quango board. This type of patronage is not possible within most western Weberian bureaucracies. By increasing the participation of (groups of) voters in the implementation of policies, their commitment - and, hence, their electoral support - to politicians will increase.

Based on these suppositions, it would seem logical to expect politicians at all times to prefer quangos as executive agent, as opposed to government bureaucracy. Or, as Gazendam and Homburg (1999) put it, the choice for quangos is the most politicially efficient choice. However, politicians have to take the economic aspects of policy implementation (efficiency and effectiveness) into account as well.

Efficient and effective implementation of policies offers politicians the opportunity to either implement more policies from the same budget or reduce taxes. Both options will be appreciated strongly by voters and increase electoral support. However, there does not seem to be an a priori reason to assume that either bureaucracy or a quango is always the most economically (in-)efficient executive agent. Both have characteristics that induce and impede efficiency or effectiveness.

Bureaucracy has the benefits of longstanding experience with policy implementation and, as a result, a longstanding relationship with politicians. The need to invest in monitoring is, therefore, usually considered to be low. The large scale of the governmental bureaucracy allows the efficient use and/or redeployment of particular assets (knowledge, equipment) but makes innovation often more difficult and expensive because of high internal coordination costs.

Quangos, in contrast, are usually established to implement just one particular policy. Knowledge and technologies are not redeployed for other use, which reduces efficiency. The main potential efficiency gains of quangos lie in the reduction of coordination costs. Putting policy implementation at arm's length means that politicians no longer have to deal with all the details of daily operational activities. However, monitoring costs increase because politicians still need information to meet the demands of their (now limited) political responsibility.

To sum up, choosing a quango as an executive agent can lead to a gain in electoral support due to the benefits of patronage and limited responsibility. If, however, the choice made leads to inefficient and ineffective policy implementation, the resulting loss of votes may exceed the benefits. Politicians will have to weigh the potential gains of their choice against the 
losses. The situational constraints under which they make their decision may vary, leading to different choices.

\section{Conditions Affecting Politicians' Choice for Quangos}

There is a large number of possible situational constraints that could influence politicians' choice. In the following, eight conditions are described and explained. The rationale for choosing these conditions is also presented.

\section{Political Ideology}

Of course, ideology plays a major role in the process of policy design and policy adoption. Its role in decisions on the type of executive agent is assumed to be much less important though. The benefits of reduced ministerial responsibility and patronage will appeal to all politicians, irrespective of their ideological preferences. Other conditions or situational constraints, such as the type of task and policy sector concerned, are expected to exert much more influence. The following hypothesis is formulated:

Hypothesis 1: Politicians with different political ideologies do not differ in their choice for quangos as an executive agent, as opposed to government bureaucracy.

\section{Economic Conditions}

Following practitioner theory, politicians can be expected to prefer quangos in times of economic downswing, because the anticipated efficiency gains can relieve fiscal stress. However, the opposite may also be true: in times of economic upswing, one could expect more quangos. Economic upswing can lead to an expansion of government tasks. More policies need to be implemented and the probability that quangos are charged with these tasks increases. So, economic conditions are not expected to be decisive to politicians' choice: they may, however, lead to different ways of establishing quangos. In times of economic downswing, quangos are more likely to be created by hiving off parts of, for example, a ministry, whereas, in times of upswing, private organizations are hived into the public sector and turned into quangos. All in all, however, politicians' choice of quangos is not expected to be influenced by economic conditions:

Hypothesis 2: Differences in economic conditions will not influence the choice of politicians for quangos as an executive agent, as opposed to government bureaucracy. 
So, neither political ideology nor economic conditions are - contrary to common sense - expected to be decisive with respect to the choice of politicians for quangos. What then are the conditions that do influence this choice? Politicians are expected to choose the executive agent that maximizes the opportunities to increase electoral support. Therefore, the higher the potential increase in electoral support is, the more politicians will be inclined to prefer quangos to government bureaucracy. In the following, two conditions are discussed that can increase electoral support: electoral competition and corporatism.

\section{Electoral Competition}

When the competition for votes is strong among politicians, they need to ensure their electoral support and will search for opportunities to boost the number of supportive voters. Competition is fierce in election years or when the differences in electoral support for politicians (or parties) are small. In such situations, to increase support and improve one's bargaining power in the cooperative efforts necessary for the adoption of policies and the decisions on policy implementation, politicians will use every means to increase electoral support. Quangos not only offer the opportunity to increase the commitment of (groups of) voters through patronage, they also reduce potential political risks, because the responsibility of politicians for policy implementation becomes limited. Both mechanisms could lead to an increase in electoral support. This brings us to the following hypothesis:

Hypothesis 3: The stronger the electoral competition among politicians is, the more often will they choose quangos to government bureaucracy for the implementation of policies.

\section{Corporatism}

Participation of interest groups is expected to increase electoral support because of the patronage effect discussed before. In situations with many interest groups, the potential gain of votes is larger than in situations where there are only a few interest groups - unless these are large groups, of course. Therefore, I expect more quangos to be established in policy sectors with many interest groups (corporatist sectors) than in fields with fewer interest groups:

HYPOTHESIS 4: In corporatist policy sectors, politicians will more often choose quangos, rather than government bureaucracy, as an executive agent, than in non-corporatist policy sectors. 
So far I have discussed conditions under which it is beneficial for politicians to choose quangos as executive agents, because it induces the opportunity to gain votes. However, there are also cases where the choice for quangos can diminish electoral support. The benefits of patronage and limited responsibility are then reduced strongly, or exceeded by the costs of inefficiency. Two such conditions are discussed next: collective goods and specific investments.

\section{Collective Goods}

Voters expect the government to provide collective goods. Therefore, I expect politicians to prefer government bureaucracy to quangos as executive agents when collective goods are concerned. The potential benefits of limited responsibility for quangos (i.e. lower political risks) are outweighed by the loss of opportunities to claim successful policy implementation concerning goods. Moreover, politicians want to be able to exert direct control and intervene at will, not only to prevent ill performance and reduce political risks but also to guarantee re-election by demonstrating to the voters how well their interests are being served. The opportunities for direct control and intervention are better in a government bureaucracy. When dealing with quangos, they are limited and often more expensive (because of extra monitoring costs). Therefore, my contention is that the greater the extent to which a good or service that has to be provided bears the characteristics of a collective good - i.e. non-exclusiveness and jointness of supply - the less likely it is that politicians will charge quangos with its provision:

HYPOTHESIS 5: The more policy implementation resembles the provision of collective goods, the less likely it is that politicians will choose quangos as executive agent, rather than government bureaucracy.

\section{Specific Investments}

Policy implementation requires investments in knowledge, equipment, technology and other assets. The more task-specific these investments are, the harder it is to redeploy them to alternative use, without loss of productive value, and the higher the risk of inefficiency becomes (Williamson, 1989: 142). The large-scale implementation of policy by government bureaucracy necessitates the presence of a large number of assets at all times, which makes redeployment easier and enhances efficiency and effectiveness. Take, for example, the fact that policy implementation often requires legal knowledge. In a ministry, a legal unit that advises all other units can be established (redeployment of knowledge). A quango would have to consult a legal specialist on matters concerning the policy that has to be implemented but 
can consult that specialist only on that policy (i.e. it is a non-recurrent investment). ${ }^{4}$ Policy implementation by government bureaucracy will, therefore, be more efficient and effective. Following the ideas of transaction cost analysis (Williamson, 1989: 150-1), I would, in the case when specific investments are necessary, expect politicians to prefer government bureaucracy (see vertical integration) to quangos (see market) when it comes to choosing an executive agent.

Specific assets may also create a (semi-)monopoly for agents. Sunk costs make it very expensive for dissatisfied politicians to choose another agent. ${ }^{5}$ Politicians might even become dependent on such an agent, particularly because most agents have a legal monopoly on policy implementation. White (1991) refers to this as reversal of control. A dependent principal might be forced to accept a certain level of inefficiency or ineffectiveness. Or, inefficiency or ineffectiveness go unnoticed, because there are no competitors with which to compare the agent's performance.

Reversal of control can occur with all agents, either government bureaucracies or quangos. However, as specific investments are made less often in a bureaucracy, because resources or assets are already available and can be more easily redeployed, the risks of choosing bureaucracy as an executive agent will appear lower to politicians. Moreover, because politicians own all production rights of the bureaucracy, they can exert immediate control over its activities, which is not the case with quangos. In quangos, the opportunities for control are limited and the distance between politicians and agent is greater. Hence, politicians will prefer government bureaucracy to quangos, when specific investments are involved (see Ter Bogt, 1994: 215):

Hypothesis 6: The more specific the investments required for policy implementation are, the less likely it is that politicians will choose a quango as the executive agent.

Until now I have implicitly assumed that politicians are capable of making a well-considered choice or, in other words, that they are fully informed about all the costs and benefits that a particular choice would bring. However, this does not seem a truly realistic assumption. The amount of information actors can assess and comprehend is limited. Herbert Simon labeled this

4. Of course, quangos could share specific assets. However, the costs of negotiating the investment and use of assets would still lead to higher average costs than investments made by a government bureaucracy.

5. It can also be argued that expensive specific investments and/or low usage frequency of assets could be a reason for politicians to hive them off or privatize policy implementation. However, such high and very specific transaction costs raise the problem of finding investors (or shareholders) willing to invest (see Hazeu, 2000: 77-9). 
‘bounded rationality' (1976: 40-1; see also Williamson, 1989: 138-9). Here, bounded rationality means that politicians cannot be entirely certain whether, under the circumstances, their choice for a certain executive agent is indeed the best - the most efficient and effective - and will enable them to maximize physical well-being and social approval.

To reduce uncertainty, individuals will seek information (Rogers, 1995; Dolowitz and Marsh, 1996: 347). Politicians can use several strategies when gathering information. The first is imitation, which means that politicians ex ante use information on efficient and effective agents. The second strategy is monitoring, which provides ex post information on the efficiency and effectiveness of policy implementation. Monitoring can also be used to give voters an account of the efficiency and effectiveness of policy implementation. Both strategies will thus increase the possibilities for politicians to make the 'best' choice, gain electoral support and secure re-election. Gathering information requires investment of time and money, however, and increases the costs of policy implementation. Therefore politicians will try to use cost-saving strategies.

\section{Imitation}

Imitation is a simple and cheap method of using information, gathered by other people. Politicians can, for example, copy the choice of other politicians for a certain type of agent (see, e.g., Pollitt et al., 2001 on contract agencies). For example, politicians will look for examples of the use of quangos in other countries, regions, levels of government and/or policy sectors. If quangos are perceived to be efficient and effective, politicians will copy the choice for that type of agent, ${ }^{6}$ which will result in an increase in the number of (that type of) quangos. To further maximize the benefits of imitation, politicians can copy the choice for a certain type of agent straightforwardly, choosing an agent with similar characteristics, tasks and operating in similar policy fields. The phenomenon where, in different sectors of society, policy sectors or countries, more and more similar organizations are established is called isomorphism (DiMaggio and Powell, 1983: 151).

A second type of imitation concerns the acquisition of information by gradually building up experience with particular types of agents, through either experimentation or the repetition of choices. By gradually increasing

6. By implication, if the choice for a quango as an executive agent is not perceived as successful, politicians will not repeat that choice. This need not always be the case, however. As was argued before, the political responsibility for policy implementation by quangos is limited. Therefore, politicians can repeat their choice for a quango even if its performance is not regarded successful, because it is not the politicians who are held accountable for ill performance but the quango. 
their experience, politicians will accumulate information that will reduce their uncertainty. When having been evaluated as a successful choice, quangos will be chosen more often as an agent. Moreover, they will be used in an increasingly diversified way:

Hypothesis 7: The more information about and experience with quangos politicians acquire, the more often will they choose quangos rather than government bureaucracy as executive agents: quangos will be used for a greater variety of tasks and set up in an increasing number of policy sectors.

\section{Monitoring}

Monitoring provides politicians ex post with information on the performance of agents. They can use this information to evaluate whether their choice of agent was successful and should be repeated (imitation). Moreover, politicians can use the information to show voters in what a good way policies are implemented, and thus secure electoral support. However, there are two problematic aspects to monitoring. First, it requires investment (so-called monitoring costs; Arrow in Pratt and Zeckhauser, 1991) which will increase the costs of policy implementation and create possible inefficiencies. To avoid inefficiencies, politicians will try to minimize monitoring costs. Monitoring costs are expected to be lower for government bureaucracies than for quangos.

The opportunities to intervene in the activities of quangos are limited. However, politicians can use alternative monitoring devices for quangos that do not require additional investments. For example, the participation by interest groups (i.e. patronage) can be viewed as a way of making quangos more accountable to the demands of citizens. Monitoring is, thus, replaced by 'accountability to the market', which is expected to ensure efficiency and reduce the need for monitoring by politicians (see Waldegrave, 1993; Stone, 1995).

A second problem is that monitoring devices - such as compulsory publication of annual reports and annual accounts - have to be imposed at the time an agent is charged with policy implementation (hence ex ante), because accountability requirements have to be laid down in the agent's statutes. The wish to minimize monitoring costs can induce politicians to impose no requirements until these prove necessary (Leeuw, 1995). In other words, politicians decide to trust the executive agent until it is found 'guilty' of inefficiency. To sum up, monitoring can be used to gather information on agents and reduce the uncertainty of politicians regarding the effects of their choice. At the same time, politicians want to minimize monitoring costs. This observation leads to the following hypothesis: 
HYPOTHESIS 8: When policy implementation requires large investments in monitoring, politicians will less often choose quangos as an executive agent, rather than government bureaucracies.

Table 2 summarizes these hypotheses and their expected effects. Now, we turn to the testing of these hypotheses.

\section{Research Design: Data Sources, Operationalizations and Methods}

Most research into quangos is case study based. There are hardly any databases available on large numbers of quangos. For this study I have used a database collected by the Dutch Court of Audit (Algemene Rekenkamer, 1995) on Dutch ZBOs (henceforth referred to as the NCA survey). Additional data were collected from a number of secondary sources, including the Dutch State Directory and The Netherlands Bureau of Statistics (CBS). See Table 2 for an overview of all sources.

The availability of the NCA survey is unique but, as with all secondary sources, also not without problems. Most problematic is the one-sidedness of the information. There is no information on the choice of politicians for government bureaucracy as an executive agent, only information on the number of decisions to establish ZBOs. Therefore, it has to be assumed that within the population of choices of an executive agent, choosing government bureaucracy is the same as not choosing a quango. This implies, however, that conclusions based on this study relate to conditions that induce quango proliferation and not to conditions that discourage the choice of government bureaucracy as an executive agent.

The dependent variable is the number of decisions to establish a quango per year or the number of quangos established per year (because one decision can lead to more than one quango). A decision is measured as the passing of the law by which a ZBO is established. Between 1950 and 1993, the number of decisions per year ranges from 0 to 10 , leading to maximum 28 quangos being established in one year (all outliers censored at 28). Note that the number of cases in the analysis equals the number of years $(N=44)$.

To measure the independent variables per year, some aggregations had to be made of the characteristics of individual decisions per year, by means of a weighting formula. For example, corporatism in a particular year is the sum of the degree of corporatism in those policy sectors where quangos were established, weighted according to the number of established quangos in those sectors. A similar approach was used for collective goods and specific 
Table 2. Overview of hypotheses, operationalizations and data sources

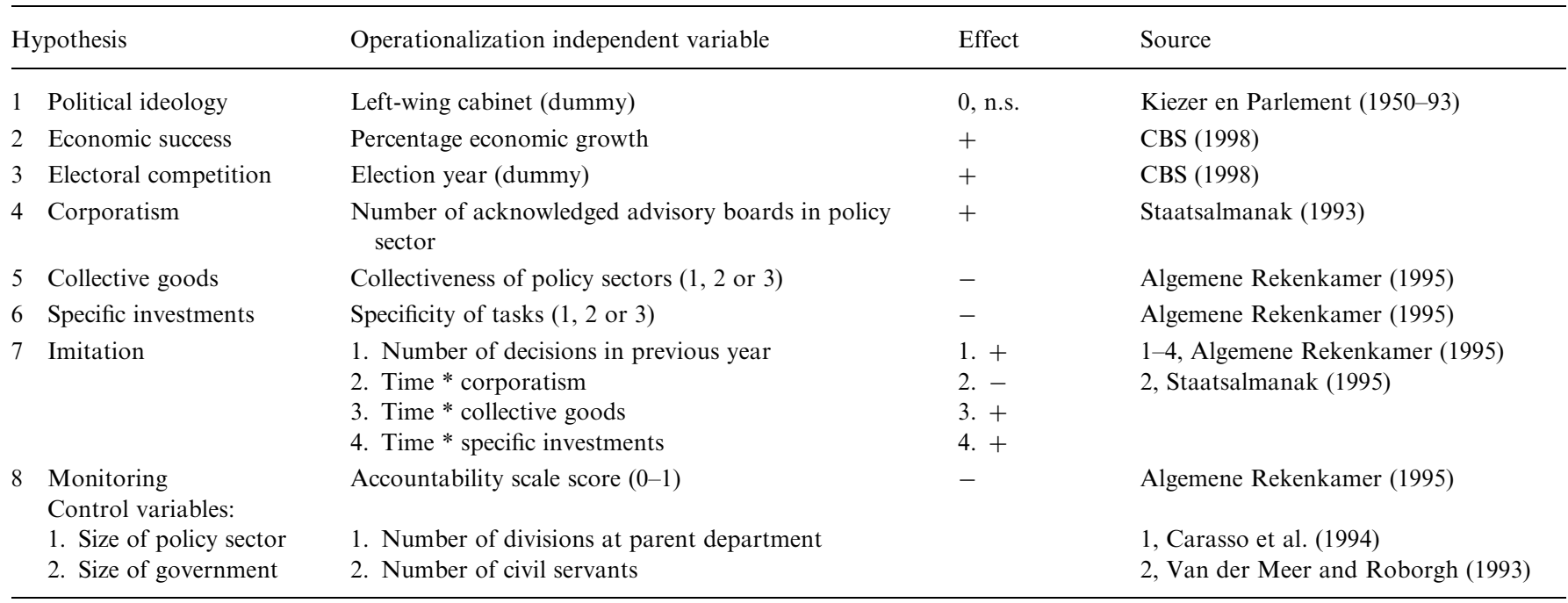

0 , no effect; + , positive effect; - , negative effect; \pm , mixed prediction; n.s., not statistically significant 
investments. ${ }^{7}$ Moreover, a time-lag was applied to most variables because it takes time to develop and pass a law to establish a quango. Analyses were performed with a time-lag of one year and four years. Here, only the results for a one-year time-lag are reported.

Linear regression is considered an appropriate method of analysis. Inspection of the data reveals two problems, however. First, auto-correlation was found in the dataset; i.e. the number of decisions to establish quangos in year $t$ is influenced by the number of decisions in year $t-1$ (Berry and Feldman, 1985: 76). The introduction of time-related explanatory variables in the regression analysis (e.g. time, imitation variables) is expected to solve this problem. ${ }^{8}$ Second, the dependent variable is a count variable. As counts are always positive integers and have a high variance, their distribution is not normal and the application of (ordinary) linear regression inappropriate (Long, 1997). Instead, a method of analysis should be used which is based on a Poisson distribution. A Poisson regression analysis was used to analyze the number of decisions to establish quangos. Because of the presence of over-dispersion, the analysis of the number of established quangos was done by means of a Negative Binomial Regression Analysis (NBRA, see Long, 1997: 230-49). ${ }^{9}$

\section{Results of the Analyses}

Based on the theoretical model, three models are tested. First, the base model consists of three control variables: time, size of government and size of policy sector. This model is used to make sure that the analyzed increase in the number of quangos is more than just an autonomous trend. Second, the

7. For 'collective goods' and 'specific investments' weights were appointed to particular policy sectors and tasks of quangos respectively. For example, Foreign Affairs and Finances were considered high on collective goods, while Agriculture and Traffic were considered low on collective goods. And supervision and quasi-judicature were considered very specific tasks, whereas coordination and research were seen as not very specific. The analyses were carried out with several weights but results did not vary. In the analyses presented here, the following weights were used: 3 (high), 2 (moderate) and 1 (low).

8. A regression analysis confirmed the presence of autocorrelation (Durbin Watson coefficient $D W=1.40)$. The introduction of the additional explanatory variables $t$ and $Y_{t-1}$ solved this problem $(D W=1.98 ; D W=2$ means no autocorrelation).

9. Over-dispersion means that the variance of the dependent variable exceeds its mean (see Barron, 1992: 179-90; Agresti, 1996: 92; Land et al., 1996: 388). For over-dispersion, Poisson regression analysis leads to overestimation of statistical significance. NBRA is a more 'skeptical' method than Poisson regression (Gardner et al., 1995: 399-402) and gives a better fit because it is more flexible (see Land et al., 1996: 392-4). NBRA tests for the presence of over-dispersion, indicated by alpha. 
Table 3. Results of Poisson Regression Analysis of the Number of Decisions per Year to Establish Quangos, The Netherlands, 1950-93 ( $N=43$, Time-lag 1 Year)

\begin{tabular}{|c|c|c|c|c|c|c|}
\hline \multirow{3}{*}{$\begin{array}{l}\text { Explanatory variables } \\
\text { Time }\end{array}$} & \multicolumn{6}{|c|}{ Coefficients ( $z$-value) } \\
\hline & \multicolumn{2}{|c|}{ Base model } & \multicolumn{2}{|c|}{ Rational actor model } & \multicolumn{2}{|c|}{ Bounded rationality model } \\
\hline & -.03 & $(1.25)$ & $-.06^{\mathrm{a}}$ & $(-2.05)$ & -.03 & $(-.89)$ \\
\hline Size of government & $4.41^{\mathrm{b}}$ & $(2.59)$ & $5.76^{\mathrm{b}}$ & (2.94) & 2.95 & $(1.31)$ \\
\hline Size of policy sector & -6.32 & $(-1.77)$ & -7.08 & $(-1.89)$ & -7.06 & $(-1.83)$ \\
\hline Left-wing cabinet & & & .36 & (1.73) & .31 & $(1.40)$ \\
\hline Economic growth & & & -.03 & $(-1.14)$ & -.04 & $(1.08)$ \\
\hline Elections & & & $-.77^{\mathrm{b}}$ & $(-2.94)$ & $-1.24^{\mathrm{c}}$ & $(-3.98)$ \\
\hline Corporatism & & & -.07 & $(-.22)$ & .02 & $(.06)$ \\
\hline Collectiveness & & & .16 & $(.63)$ & .08 & $(.30)$ \\
\hline Specific investments & & & -.14 & $(-.46)$ & -.02 & $(-.06)$ \\
\hline Previous decisions & & & & & $.14^{\mathrm{b}}$ & $(2.70)$ \\
\hline Time $*$ corporatism & & & & & .03 & $(1.04)$ \\
\hline Time $*$ collectiveness & & & & & -.02 & $(-.82)$ \\
\hline Time $*$ specificity & & & & & -.02 & $(.48)$ \\
\hline Monitoring & & & & & $1.16^{\mathrm{a}}$ & $(2.44)$ \\
\hline Constant & -9.21 & $(-.93)$ & -13.75 & $(-1.29)$ & -1.58 & $(-.13)$ \\
\hline Log-likelihood & -84.08 & & -77.07 & & -67.95 & \\
\hline Pseudo $R^{2}$ & .15 & & .22 & & .31 & \\
\hline
\end{tabular}

${ }^{\mathrm{a}} p<.05 ; \quad \mathrm{b} p<.01 ; \quad{ }^{\mathrm{c}} p<.001$. 
rational actor model that, besides the control variables, also includes the conditions specified in Hypotheses 1-6. This model is called the rational actor model because it assumes politicians to be rational actors. This assumption is released in the third model, the bounded rationality model. Imitation and monitoring are added as explanatory variables to the rational actor model. Tables 3 and 4 show the results.

\section{Base Model}

Quango proliferation is partly an autonomous trend. The increase in the number of quangos is related to the increase in the government size. Apparently, bureaucratization and quango proliferation go hand in hand, contrary to what is often suggested by practitioner theory.

\section{Rational Actor Model}

Political ideology has no (statistically significant) influence on the number of decisions to establish quangos. Hypothesis 1 is thus confirmed. Economic conditions do not appear to be decisive to politicians' choice either. Hypothesis 2 can, therefore, be considered to be confirmed as well.

Hypothesis 3 is refuted: contrary to the expectation, competition for votes between politicians leads to fewer decisions to establish quangos. Elections lead to fewer decisions to establish quangos. Perhaps politicians are less interested in policy implementation during elections, giving priority to the development of new ideas and policies to please voters. Politicians consider the choice of an executive agent as less salient to voters.

Neither the degree of corporatism nor the degree of 'collectiveness' in policy sectors is found to be of importance to politicians' decisions. Hypotheses 4 and 5 are, therefore, neither confirmed nor refuted.

Politicians do not decide to charge quangos with tasks that require specific investments more often but if they do the executive agent is usually a cluster of quangos. Most Dutch ZBOs (74.5 percent) belong to a cluster, although only 13.7 percent of the decisions result in the establishment of a cluster. The conclusion is that quangos are charged more often with specific tasks. Hypothesis 6 is rejected.

An explanation for this finding can perhaps be found in the typical nature of specific tasks. Although it is probably true that in a large government bureaucracy assets such as knowledge and equipment can be more easily redeployed, there are disadvantages associated with keeping specific tasks within a government bureaucracy. For example, specific tasks can be seen as a deviation from standard operating procedures (Wilson, 1989: 133) or a disturbance of bureaucratic routines. Managing such tasks could take up much time or require skills and expertise that are not available. Charging a 
Table 4. Results of Negative Binominal Regression Analysis on the Number of Established Quangos, Per Year, The Netherlands, $1950-93(N=43$, Time-lag 1 Year $)$

\begin{tabular}{|c|c|c|c|c|c|c|}
\hline \multirow{3}{*}{$\begin{array}{l}\text { Explanatory variables } \\
\text { Time }\end{array}$} & \multicolumn{6}{|c|}{ Coefficients ( $z$-value) } \\
\hline & \multicolumn{2}{|c|}{ Base model } & \multicolumn{2}{|c|}{ Rational actor model } & \multicolumn{2}{|c|}{ Bounded rationality model } \\
\hline & -.05 & $(-.74)$ & -.01 & $(.22)$ & .06 & $(1.01)$ \\
\hline Size of government & 3.40 & $(.71)$ & .38 & $(.10)$ & -2.83 & $(-.77)$ \\
\hline Size of government sector & 13.88 & $(1.90)$ & 6.74 & $(.96)$ & 4.24 & $(.63)$ \\
\hline Left-wing cabinet & & & .31 & $(.76)$ & .37 & $(.96)$ \\
\hline Economic growth & & & .05 & $(.74)$ & -.01 & $(-.18)$ \\
\hline Elections & & & -.19 & $(-.33)$ & -.48 & $(-.87)$ \\
\hline Corporatism & & & -.55 & $(-.90)$ & -.24 & $(-.43)$ \\
\hline Collectiveness & & & -.56 & (1.09) & .37 & $(.79)$ \\
\hline Specific investments & & & $1.25^{\mathrm{a}}$ & $(2.18)$ & $1.47^{\mathrm{b}}$ & $(2.58)$ \\
\hline Previous decisions & -.03 & $(-1.26)$ & & & & \\
\hline Time $*$ corporatism & & & & & .02 & $(-.44)$ \\
\hline Time $*$ collectiveness & & & & & -.08 & $(-1.68)$ \\
\hline Time * specificity & & & & & -.02 & $(.42)$ \\
\hline Monitoring & & & & & $1.83^{\mathrm{a}}$ & (1.98) \\
\hline Constant & -37.03 & $(-1.24)$ & -14.02 & $(-.61)$ & 4.33 & $(.20)$ \\
\hline Log Likelihood & -133.69 & & -127.59 & & -123.56 & \\
\hline Pseudo $R^{2}$ & .02 & & .06 & & .09 & \\
\hline Alpha & $1.67^{\mathrm{c}}$ & & $1.18^{\mathrm{c}}$ & & $.94^{\mathrm{c}}$ & \\
\hline
\end{tabular}

${ }^{\mathrm{a}} p<.05 ; \quad{ }^{\mathrm{b}} p<.01 ; \quad{ }^{\mathrm{c}} p<.001$. 
quango with policy implementation would solve these problems: a quango is not part of the core government bureaucracy, which allows for the involvement of external experts, in particular members of interest groups or voluntary organizations, to ensure efficiency of policy implementation. The interest of private organizations in these tasks will probably be low, therefore a quasi-autonomous organization is charged with them.

An additional benefit of putting specific tasks at arm's length is a reduction in the political risk of being held accountable for ill performance. If the bureaucracy is indeed less well equipped to carry out a certain task, the risk of ill performance increases and also the risk that politicians will be held accountable. Charging a quango with the task reduces that risk. It might even be argued that politicians deliberately put the implementation of highly specific policies at arm's length when these policies are considered controversial (see Torenvlied, 2000). In case of ill performance, the quango will be held accountable.

In sum, the rational actor model does not provide much more explanation for quango proliferation than the base model did. The increase in the number of quangos cannot be attributed to particular political parties or to economic conditions. The tasks of quangos did not appear decisive either to the decision to establish a quango, nor were characteristics of policy sectors such as corporatism. Electoral competition was even found to lead to fewer quangos instead of the expected increase in their number.

\section{Bounded Rationality Model}

Politicians are inclined to repeat their decision to establish quangos. If more decisions in favor of quangos were taken in the previous year, politicians are more likely to decide to charge a quango with policy implementation in the present year. The repetition of decisions confirms Hypothesis 7. The diversity trend is contrary to the one expected, however. Apparently, the number of quangos charged with the provision of collective goods has decreased, instead of increased. The diversity of quangos has, therefore, increased, albeit in the opposite direction of the one predicted.

Finally, Hypothesis 8 is refuted. An increase in the number of decisions to establish quangos is met with an increase in the degree of monitoring. Apparently, politicians do not refrain from establishing quangos if monitoring costs will have to be made. The analysis further shows that politicians impose requirements on quangos more often if the task in question is charged more frequently to quangos. Earlier, it was assumed that politicians would want to minimize monitoring costs. By imposing (the same) requirements in the same instances, the average monitoring costs will decrease. For example, requirements are imposed more often on quangos with specific tasks (unless these tasks resemble the provision of collective goods). An extra 
argument to explain the presence of high monitoring demands in the case of specific tasks could be that politicians fear the possible consequences of the information asymmetry. Because the expertise and knowledge about a policy and its implementation is concentrated in a quango (sunk costs), politicians depend on that quango for information on its performance. The recent re-assertion of political authority (see below) seems to indicate that politicians have become aware of this potential dependency.

The publication of reports on the increase in the number of quangos and, more particularly, the lack of democratic accountability by these bodies (see Algemene Rekenkamer, 1995 for The Netherlands and Hall and Weir, 1996 for the United Kingdom) have led to several measures to repair the lack of justification. Examples of this re-assertion of political control (see Rhodes, 1997) are the white papers on Modernizing Government and Joined-up Government in the UK, the development of guidelines and a law proposal on ZBOs in The Netherlands and the increase in the use of regulators and performance assessment in general in most OECD countries (see Power, 1997; Van Thiel and Leeuw, 2002).

\section{Comparison of the Three Models}

The bounded rationality model gives the best fit of all models. Moreover, the theoretical model provides a better prediction of the decisions of politicians to charge a quango with policy implementation than the number of quangos established as a result of those decisions. Quango proliferation is caused by an increase in the size of the government and the repetition by politicians of their choice for a quango as an executive agent. The explanatory power of this model still leaves room for improvement, though (pseudo $R^{2}$ does not exceed .31).

\section{Conclusions}

This article investigates the motives of politicians to use quangos increasingly for the execution of public tasks. It shows that political and economic conditions are not decisive and, to a lesser degree, neither are the tasks in question. Overall, quango proliferation turns out to be a trend. Politicians imitate previous decisions. This could imply that they are not certain about the effects of their choice for quangos.

What information do politicians have about the use of quangos? The information on the performance of quangos is growing but remains mixed and contradictory (Naschold, 1996; Boyne, 1998; Ter Bogt, 1999; Pollitt, 2001; Van Thiel, 2001). The establishment of quangos is, in itself, no guarantee that the efficiency or quality of policy implementation will improve, as 
assumed in practitioner theory. Nevertheless, politicians still continue to establish contract agencies, public bodies and use privatization and competitive tendering (see Pollitt and Talbot, 2004). Perhaps there are other benefits for politicians associated with quango proliferation. Two advantages have already been identified: blame avoidance and patronage. Moreover, the incremental expansion of the number of a certain type of agent creates legitimacy (Tolbert and Zucker, 1982: 30). Gradually, the choice for that type of agent becomes more common and accepted by voters. In the end, it will become the most legitimate type of executive and politicians will choose that agent merely to please the voters. Their choices are no longer based on efficiency arguments but have become symbolic choices (Rowan and Meyer, 1977: 361).

To understand how this imitation works better, the model as presented in this article needs to be expanded and elaborated further. There are at least four new research questions one can pose.

First, why would politicians imitate each other? Theories on innovation diffusion (Rogers, 1995), policy transfer (Bennett, 1991; Dolowitz and Marsh, 1996), and isomorphism (DiMaggio and Powell, 1983; Powell and DiMaggio, 1991) present interesting explanations. For example, supranational organizations such as the World Bank or the European Union may force states to adopt certain models of government such as contract agencies (see Pollitt et al., 2001) and competitive tendering (Van Thiel, 2004).

Second, which actors play which role in imitation? In the model described here, only politicians are discussed but other actors such as civil servants will undoubtedly play an important role as well. Dunleavy's (1991) theory of bureau-shaping could be used to explain the interest civil servants may have in the hiving off of departmental units and the establishment of quangos (see also Christensen, 1999).

Third, how far does imitation go? Basically, the 'story' on the spread of quangos - or NPM in general - is that governments faced with global economic pressures charge organizations at arm's length with the execution of policy tasks, because such organizations are believed to be more efficient than government itself. While some authors believe this trend is irreversible and inescapable (Osborne and Gaebler, 1992), others argue that western states have responded in different ways to fiscal pressure and the public's dissatisfaction with governments. NPM techniques have been implemented following different trajectories and adapted to the existing institutional context (Pollitt and Bouckaert, 2000). Rather than straightforward imitation, countries have emulated, adjusted and hybridized the quango concept. So, convergence in the adoption of NPM talk is evident (see OECD, 2001) but variations between and within countries do exist in implementation, types and results (Pollitt, 2001). Such differences are determined by, for example, the political system of countries. 
Finally, what are the consequences of the increased use of quangos? Most debated so far is the potential democratic deficit (see Kettl, 1997: 457; Skelcher, 1998). Politicians have begun to become aware of the effects of increased use of quangos. They have responded by taking a number of measures to re-assert their political authority (see earlier). But there are other consequences as well quango performance, in particular, that are in need of further study.

\section{Acknowledgements}

I would like to thank Frans Leeuw, Jacques Siegers and Henk Flap (all professors at Utrecht University, The Netherlands) for their support, comments and ideas that underpin the work presented here.

\section{REFERENCES}

Algemene Rekenkamer (1995) Verslag 1994. Deel 3: Zelfstandige bestuursorganen en ministeriële verantwoordelijkheid. Tweede Kamer, vergaderjaar 1994-1995, No. 3, pp. 24-130. The Hague: Sdu.

Agresti, A. (1996) An Introduction to Categorical Data Analysis (Wiley Series in Probability and Statistics). New York: John Wiley \& Sons.

Barker, A., ed. (1982) Quangos in Britain. London: Macmillan.

Barron, D.N. (1992) 'The Analysis of Count Data: Overdispersion and Autocorrelation', Sociological Methodology 24: 179-220.

Bennett, C.J. (1991) 'What is Policy Convergence and What Causes It?', British Journal of Political Science 21: 215-33.

Berry, W.B. and S. Feldman (1985) Multiple Regression in Practice (Quantitative Applications in the Social Sciences 50). Newbury Park: Sage.

Boston, J. (1995) 'Lessons from the Antipodes', in B. O'Toole and G. Jordan (eds) The Next Steps: Improving Management in Government?, pp. 161-77. Aldershot: Dartmouth.

Boyne, G. (1998) 'Bureaucratic Theory Meets Reality: Public Choice and Service Contracting in US Local Government', Public Administration Review 58(6): 474-84.

Carasso, L.C., J.M.P. Koopmans, J.C.N. Raadschelders and I.F.J. Voermans (1994) 'Organisatiedifferentiatie bij de rijksoverheid in historisch perspectief', Bestuurswetenschappen 6: 483-95.

Centraal Bureau voor de Statistiek (CBS) (1998) Tijdreeksen. URL: http://www.cbs.nl

Christensen, J. (1999) 'Bureaucratic Autonomy as a Political Asset', Paper presented at workshop 'Politicians, Bureaucrats and Institutional Reform', ECPR Joint Sessions of Workshops, Mannheim, 26-31 March.

Cohn, D. (1997) 'Creating Crises and Avoiding Blame: The Politics of Public Service Reform and the New Public Management in Great Britain and the United States', Administration \& Society 29(5): 584-616.

Coleman, J.S. (1990) Foundations of Social Theory. Cambridge, MA: The Belknap Press of Harvard University Press. 
DiMaggio, P.J. and W. W. Powell (1983) 'The Iron Cage Revisited: Institutional Isomorphism and Collective Rationality in Organizational Fields', American Sociological Review 48: 14760 .

Dolowitz, D. and D. Marsh (1996) 'Who Learns What From Whom: A Review of the Policy Transfer Literature', Political Studies XLIV: 343-57.

Downs, A. (1965) Non-market Decision Making: A Theory of Bureaucracy', American Economic Review 54: 439-46.

Dunleavy, P. (1991) Democracy, Bureaucracy and Public Choice: Economic Explanations in Social Science. New York: Harvester Wheatsheaf.

Dunleavy, P. (1994) 'The Globalization of Public Services Production: Can Government Be "Best in World"?', Public Policy and Administration 9(2): 36-65.

Flinders, M. V. and M. J. Smith, eds (1999) Quangos, Accountability and Reform: The Politics of Quasi-government, pp. 26-39. London: Macmillan.

Gardner, W., E. P. Mulvey and E. C. Shaw (1995) 'Regression Analyses of Counts and Rates: Poisson, Overdispersed Poisson and Negative Binomial Models', Psychological Bulletin 118: 392-404.

Gazendam, H. W. M. and V. M. F. Homburg (1999) 'Efficiëntie en verzelfstandiging: economische en politieke efficiëntie als verklaring voor verzelfstandiging', Bestuurskunde 8: 19-27.

Greve, C. (1999) 'Quangos in Denmark and Scandinavia: Trends, Problems and Perspectives', in M. V. Flinders and M. J. Smith (eds) Quangos, Accountability and Reform: The Politics of Quasi-government, pp. 83-108. London: Macmillan.

Greve, C., M. V. Flinders and S. van Thiel (1999) 'Quangos: What's in a Name? Defining Quangos from a Comparative Perspective', Governance 12(1): 129-46.

Hall, W. and S. Weir (1996) The Untouchables: Power and Accountability in the Quango State. The Democratic Audit of the United Kingdom. London: Charter 88 Trust.

Hazeu, C. (2000) Institutionele economie: een optiek op organisatie- en sturingsvraagstukken. Bussum: Uitgeverij Coutinho.

Hogwood, B. (1995) 'The "Growth" of Quangos: Evidence and Explanations', Parliamentary Affairs 48: 207-25.

Hood, C. (1994) ‘A Public Management for All Seasons?', Public Administration 69(Spring): 319.

Hood, C. and G. F. Schuppert, eds (1988) Delivering Public Services in Western Europe. London: Sage.

Kettl, D. (1997) 'The Global Revolution in Public Management: Driving Themes, Missing Links', Journal of Policy Analysis and Management 16(3): 446-62.

Kiezer en Parlement (1950-1993). Groningen: Wolters Noordhoff.

Land, K. C., P. L. McCall and D. S. Nagin (1996) 'A Comparison of Poisson, Negative Binomial, and Semiparametric Mixed Poisson Regression Models', Sociological Methods \& Research 24: 387-442.

Leeuw, F.L. (1995) 'Onbedoelde gevolgen van bestuurlijke intenties', in H. van Gunsteren and E. van Ruyven (eds) Bestuur in De Ongekende Samenleving, pp. 55-72. The Hague: Sdu.

Leeuw, F.L. and S. van Thiel (1999) 'Quangocratization in The Netherlands', in: M. V. Flinders and M. J. Smith (eds) Quangos, Accountability and Reform: The Politics of Quasi-government, pp. 72-83. London: Macmillan.

Lindenberg, S. M. (1983) 'The New Political Economy: Its Potential and Limitations for the Social Sciences in General and for Sociology in Particular', in W. Sodeur (ed.) Ökonomische Erklärung sozialen Verhaltens, pp. 1-68. Duisburg: Verlag der sozialwisschaftlichen Kooperative.

Lindenberg, S. M. and B. Frey (1993) 'Alternatives, Frames and Relative Prices', Acta Sociologica 36: 191-205. 
Long, J. S. (1997) Regression Models for Categorical and Limited Dependent Variables (Advanced Quantitative Techniques in the Social Sciences). Thousand Oaks, CA: Sage.

Modeen, T. and A. Rosas, eds (1988) Indirect Public Administration in Fourteen Countries. Finland: Abo Academy Press.

Mueller, D. C. (1989) Public Choice II. Cambridge: Cambridge University Press.

Mueller, D. C., ed. (1997) Perspectives on Public Choice: A Handbook. Cambridge: Cambridge University Press.

Naschold, F. (1996) 'Redefining Public Sector Tasks at the Interface between Public and Private Service Provision', in F. Naschold and C. von Otter (eds) Public Sector Transformation: Rethinking Markets and Hierarchies in Government, pp. 21-38. Amsterdam: John Benjamins.

Niskanen, W.A. (1975) 'Bureaucrats and Politicians', The Journal of Law and Economics 17: 61743.

Organization for Economic Development (2001) Distributed Public Governance: Agencies Authorities and Other Autonomous Bodies. Paris: OECD.

Osborne, P. and T. Gaebler (1992) Reinventing Government: How the Entrepreneurial Spirit is Transforming the Public Sector. Reading MA: Addison-Wesley.

Pollitt, C. (2001) 'Clarifying Convergence: Striking Similarities and Durable Differences in Public Management Reform', Public Management Review 3(4): 1-22.

Pollitt, C. and G. Bouckaert (2000) Public Management Reform: A Comparative Analysis. Oxford: Oxford University Press.

Pollitt, C., K. Bathgate, J. Caulfield, A. Smullen and C. Talbot (2001) 'Agency Fever? Analysis of an International Policy Fashion', Journal of Comparative Policy Analysis 3(3): 271-90.

Pollitt, C. and C. Talbot, eds (2004) Unbundled Government: A Critical Analysis of the Global Trend to Agencies, Quasi-autonomous Bodies and Contractualization. London: Taylor \& Francis.

Powell, W. W. and P. J. DiMaggio, eds (1991) The New Institutionalism in Organizational Analysis. Chicago: The University of Chicago Press.

Power, M. (1997) The Audit Society. Oxford: Oxford University Press.

Pratt, J. W. and R. J. Zeckhauser (1991) Principals and Agents. Boston, MA: Harvard Business School Press.

Rhodes, R. (1997) 'Reinventing Whitehall, 1979-1995: Hollowing Out the State?', in R. Rhodes (ed.) Understanding Governance, pp. 87-111. Buckingham: Open University Press.

Rogers, E. M. (1995) Diffusion of Innovations, 4th edn. New York: The Free Press.

Rowan, B. and J. W. Meyer (1977) 'Institutionalized Organizations: Formal Structure as Myth and Ceremony', American Journal of Sociology 83: 340-63.

Scharpf, F. W. (1997) Games Real Actors Play: Actor-centered Institutionalism in Policy Research (Theoretical Lenses on Public Policy). Oxford: Westview Press.

Simon, H. (1976) Administrative Behavior: A Study of Decision-making Processes in Administrative Organizations, 3rd edn. New York: The Free Press.

Skelcher, C. (1998) The Appointed State: Quasi-governmental Organizations and Democracy. Buckingham: Open University Press.

Staatsalmanak voor het Koninkrijk der Nederlanden (1993) The Hague: Sdu.

Stone, B. (1995) 'Administrative Accountability in the Westminster Democracies: Towards a New Conceptual Framework', Governance 8: 505-26.

Ter Bogt, H. J. (1994) 'Verzelfstandiging van overheidsorganisaties, bezien vanuit de neoinstitutionele economie', Beleidswetenschap 8: 205-39.

Ter Bogt, H. J. (1999) 'Financial and Economic Management in Autonomized Dutch Public Organizations', Financial Accountability \& Management 15(3/4): 329-48.

Tolbert, P. S. and L. G. Zucker (1982) 'Institutional Sources of Change in the Formal Structure of Organizations: The Diffusion of Civil Service Reform, 1880-1935', Administrative Science Quarterly 28: 22-39. 
Torenvlied, R. (2000) Political Decisions and Agency Performance. Dordrecht: Kluwer.

Van der Meer, F. M. and L. J. Roborgh (1993) Ambtenaren in Nederland: omvang, bureaucratisering en representativiteit van het ambtelijk apparaat. Alphen aan den Rijn: Samsom H.D. Tjeenk Willink.

Van Thiel, S. (2001) Quangos: Trends, Causes and Consequences. Aldershot: Ashgate.

Van Thiel, S. (2004) 'Quangos in Dutch Government', in C. Pollitt and C. Talbot (eds) Unbundled Government: A Critical Analysis of the Global Trend to Agencies, Quasi-autonomous Bodies and Contractualisation, London: Taylor \& Francis.

Van Thiel, S. and F. L. Leeuw (2002) 'The Performance Paradox in the Public Sector', Public Productivity \& Management Review 25(3): 267-81.

Van Thiel, S. and M. W. van Buuren (2001) 'Ontwikkeling van het aantal zelfstandige bestuursorganen tussen 1993 en 2000: zijn zbo's "uit" de mode?', Bestuurswetenschappen 55(5): 386-404.

Waldegrave, W. (1993) The Reality of Reform and Accountability in Today's Public Service. London: CIPFA, Public Finance Foundation.

White, H. C. (1991) 'Agency as Control', in J. W. Pratt and R. J. Zeckhauser (eds) Principals and Agents, pp. 187-213. Boston, MA: Harvard Business School Press.

Williamson, O. E. (1989) 'Transaction Cost Economics', in R. Schmalensee and R. D. Willig (eds) Handbook of Industrial Organization, Vol. I, pp. 136-81. Amsterdam: Elsevier.

Wilson, J. Q. (1989) Bureaucracy: What Government Agencies Do and Why They Do It. New York: Basic Books.

Wistrich, E. (1999) 'Quangos in New Zealand', in M. V. Flinders and M. J. Smith (eds) Quangos, Accountability and Reform: The Politics of Quasi-government, pp. 84-93. London: Macmillan.

SANDRA VAN THIEL is Assistant Professor of Public Administration at Erasmus University Rotterdam, The Netherlands. Her main research activities deal with the increase of the number of quasi-autonomous bodies in many western states. She is also interested in the performance of public sector organizations. She has published both internationally (Governance, Public Performance and Management Review) and in The Netherlands. In 2000 she obtained her doctorate for her dissertation on 'Quangos: Trends, Causes and Consequences' (published in 2001). Sandra van Thiel is one of the founders of the international research network on quasi-autonomous government (www.shef.ac.uk/quangos). ADDRESS: P.O. Box 173, 3000 DR Rotterdam, The Netherlands. [email to vanthiel@fsw.eur.nl] 